\title{
Phytochemical Screening, Cytotoxic and Anthelmintic Activities of Amorphophallus campanulatus (Roxb.), Avicennia marina (Forssk.) and Launaea sarmentosa (Willd.)
}

\author{
Md. Mizanur Rahman Moghal', Anik Bhattacharjee², Saifuddin Mohammad Seeam², \\ A. S. M. Monirul Islam ${ }^{3}$ and Mahadi Hassan Bappy ${ }^{2}$ \\ ${ }^{1}$ Department of Pharmacy, Mawlana Bhashani Science and Technology University, Santosh \\ Tangail-1902, Bangladesh \\ ${ }^{2}$ Department of Pharmacy, Noakhali Science and Technology University, Noakhali-3814, Bangladesh \\ ${ }^{3}$ Department of Pharmacy, University of Dhaka, Dhaka- 1217, Bangladesh
}

Received: January 08, 2015; Accepted: February 01, 2016; Published (Web): February 17, 2016

\begin{abstract}
Amorphophallus campanulatus (Roxb.), Avicennia marina (Forssk.) and Launaea sarmentosa (Willd.) are widely used plants in Asian folk and traditional medicines. In the present study, we have tried to find out the phytoconstituents, anthelmintic activity and cytotoxicity of the methanolic extracts of these plants. Anthelmintic activity was assessed by recording paralysis and death time with different concentrations of the plant extracts; while brine shrimp lethality test (BSLT) method was used to evaluate the cytotoxicity of the proposed plant extracts, where vincristine sulphate was used as positive standard control. The plant extracts demonstrated positive response in the tests for alkaloids, carbohydrates, saponins, phytosterols, phenols, flavonoids and amino acids that have huge and diverse phytochemical values. Anthelmintic test showed that methanol extract of Avicennia marina at $40 \mathrm{mg} / \mathrm{ml}$ significantly caused paralysis and death of worms and the required time were found to be $19.0 \pm 1.46 \mathrm{~min}$ and $32.67 \pm 0.95 \mathrm{~min}$, respectively which gradually increased with the decrease of concentration. A. campanulatus also showed minimum paralysis and death time of 24.66 $\pm 0.37 \mathrm{~min}$ and $38.33 \pm 0.27 \mathrm{~min}$, respectively while standard albendazole caused paralysis and death of worms after $35.33 \pm 58 \mathrm{~min}$ and $71.33 \pm 1.15 \mathrm{~min}$ of administration, respectively. In this test distilled water was used as negative control and no mortality of the worms was observed. In case of cytotoxicity measurement, the crude methanolic extract of A. campanulatus, A. marina and L. sarmentosa revealed positive result with $\mathrm{LC}_{50}$ values of $0.0005 \mu \mathrm{g} / \mathrm{ml}, 1.345 \mu \mathrm{g} / \mathrm{ml}$ and $5.652 \mu \mathrm{g} / \mathrm{ml}$, respectively as compared to standard vincristine sulphate $(0.839 \mu \mathrm{g} / \mathrm{ml})$.
\end{abstract}

Key words: Amorphophallus campanulatus, Avicennia marina, Launaea sarmentosa, anthelmintic, cytotoxicity, phytoconstituents

\section{Introduction}

Medicinal plants have been a major source of treatment for human diseases since time immemorial. One fourth of the world population i.e. 1.42 billion people are dependent on traditional medicines, particularly plant drug for curing ailments (Kala et al., 2011). Herbal medicine represents one of the most important fields of traditional medicine. WHO recognized that medicinal plants played an important role in the health care of about $80 \%$ of the world population in developing countries and depend largely on traditional medicine
(National Research Council, 1992; Pushpangadan et al., 2005). Phytochemistry or plant chemistry is concerned with the enormous variety of organic substances that are elaborated and accumulated by plants and deals with the chemical structures of these substances, their biosynthesis, turnover and metabolism, their natural distribution and biological function (Harborne, 1998). Most of the existing anthelminthic produces side effects such as abdominal pain, loss of appetite, nausea, vomiting, head ache and diarrhoea (Bundy, 1994). Since ancient times herbal drugs are used for the

Correspondence to: Md. Mizanur Rahman Moghal; Cell: +8801863288080; E-mail: pharmizan@ yahoo.com 
treatment of parasitic diseases in human without any side effects (Sondhi et al., 1994).

Amorphophallus campanulatus (Roxb.) (family: Araceae) is an annual herb with large, depressedglobose, much-warted tubers. It contains protease inhibitors, trypsin and chymotrypsin. Corm contains triacontane, lupeol, betulinic acid, stigmasterol, Bsitosterol, glucose, galactose, rhamnose and xylose. Sapogenins are also present in the corms (Ghani, 2003). The tuberous roots of the plant have been used traditionally for the treatment of piles, abdominal pain, tumors, and enlargement of spleen, asthma and rheumatism. (Kirtikar et al., 1998).

Avicennia marina (Forssk.) (family: Avicenniaceae) is a species of mangrove tree that occurs in the intertidal zones of estuarine areas (Spalding et al., 2010; Duke et al., 1998). It has smooth light-grey bark made up of thin, stiff, brittle flakes. The leaves are thick, five to eight centimetres long, a bright, glossy green on the upper surface and silvery-white, or grey, with very small matted hairs on the surface below (Boland, 1984). It releases some phytochemical compounds like phenols, tannins, azadirachtin, ricinine that are toxic to nematodes and parasites (Mianet al., 1982; Rich et al., 1989). A. marina has been used traditionally for the management of acute ulcers and skin related inflammatory diseases (Bandaranayake, 2002; Khafagi et al., 2003; Kathiresan et al., 2001). Several antiviral, (Bobbarala et al., 2009) antifungal, antibacterial (Ravikumar et al., 2010; Zandi et al., 2003), (in vitro antimalarial and cytotoxic activities (Miles et al., 1999) of A. marina have also been reported. Launaea sarmentosa (Willd.) belongs to the family Asteraceae is a perennial herb (Nadkarni, 1982). The roots of $L$. sarmentosa showed the presence of lactiferous cells, pitted vessels, simple fibers, calcium oxalate crystals, devoid of pith and contains phytochemical compounds like alkaloids, glycosides, tannin, amino acids, carbohydrates and steroids (Nagalapur et al., 2010; Salih et al., 2013). It has traditionally being used as tonic, aperients, rheumatic affections, diuretic and given as a soporific (Pullaiah, 2006). It has also popularity in the treatment of abdominal pain and disorders, urinary tract infections (Salih et al., 2013). Another study confirmed the local use of whole plant as a bath decoction to treat peripheral skin diseases (Kiritikar et al., 1935). Thus the present study was designed to evaluate the phytochemical screening, cytotoxic and anthelmintic activities of these three plants, which may lead to a new possibility in the drug exploration.

\section{Materials and Methods}

Collection and processing of plant samples: Plant samples of $A$. campanulatus, $A$. marina and $L$. sarmentosa were collected from Sonadia Dheep of Cox's Bazar and a plant sample was submitted to the Bangladesh National Herbarium for identification and the accession number are DACB: 38340 , DACB: 38311 and DACB: 38312, respectively. Plants were sun dried for seven days then grounded in coarse powder using high capacity grinding machine which were then stored in air-tight container with marking for identification and kept in cool, dark and dry place for the investigation. The powder materials (500 g each) from the plants were separately soaked in 3.0 liters of methanol at room temperature for 7 days. The extracts were filtered through fresh cotton bed and finally with Whatman filter paper number 1 . The filtrates were concentrated with a rotary evaporator at reduced temperature and pressure. These extracts were then stored in a refrigerator for further use.

Phytochemical screening: In the chemical group tests, $10 \%(\mathrm{w} / \mathrm{v})$ solution of methanol extract for each test was used unless otherwise mentioned in individual test.

Test for alkaloids: Mayer's test: $2 \mathrm{ml}$ solution of the extract and $0.2 \mathrm{ml}$ of dilute hydrochloric acid were taken in a test tube. Then $1 \mathrm{ml}$ of Mayer's reagent was added. Yellow colour precipitations is regarded as evidence for the presence of alkaloids.

Wagner's test: $2 \mathrm{ml}$ solution of the extract and 0.2 $\mathrm{ml}$ of dilute hydrochloric acid were taken in a test tube. Then $1 \mathrm{ml}$ of iodine solution (Wagner's reagent) was added. Redish brown precipitate is regarded as evidence for the presence of alkaloids.

Hager's test: $2 \mathrm{ml}$ solution of the extract and $0.2 \mathrm{ml}$ of dilute hydrochloric acid were taken in a test tube. Then $1 \mathrm{ml}$ of picric acid solution (Hager's reagent) was added. Yellowish precipitate is regarded as evidence for the presence of alkaloids. 
Tests for carbohydrate: Filtrates were treated with 2 drops of alcoholic $\alpha$-naphthol solution in a test tube and conc. Sulphuric acid was added formation of the violet ring at the junction is regarded as evidence for the presence of Carbohydrates.

\section{Tests for reducing sugar}

Benedict's test: $0.5 \mathrm{ml}$ of aqueous extract of the plant material was taken in a test tube. $5 \mathrm{ml}$ of benedict's solution was added to the test tube, boiled for 5 minutes and allowed to cool spontaneously.

Fehling's test: $2 \mathrm{ml}$ of an aqueous extract of the plant material was added $1 \mathrm{ml}$ of a mixture of equal volumes of Fehling's solutions A and B. Boiled for few minutes.

\section{Tests for cardiac glycoside}

Legal's test: Extracts were treated with sodium nitropruside in pyridine and sodium hydroxide. Formation of pink to blood red color is regarded as evidence for the presence of cardiac glycosides

\section{Test for flavonoids}

Alkaline reagent test: Extracts were treated with 45 drops of sodium hydroxide solution. Formation of intense yellow color, which becomes colorless on addition of dilute acid, indicates the presence of flavonoids.

Lead acetate test: Extracts were treated with 4-5 drops of lead acetate solution. Formation of yellow color precipitate indicates the presence of flavonoids.

Test for saponins: $1 \mathrm{ml}$ solution of the extract was diluted with distilled water to $20 \mathrm{ml}$ and shaken in a graduated cylinder for 15 minutes. One-centimeter layer of foam indicate the presence of saponins.

Test for gums: $5 \mathrm{ml}$ solution of the extract was taken and then molish reagent and sulphuric acid were added. Red violet ring produced at the junction of two liquids indicates the presence of gums and carbohydrate.

\section{Test for phytosterols}

Libermann-Burchard test: $1 \mathrm{ml}$ solution of extract was taken and then added $2 \mathrm{ml}$ Libermann-Burchard reagent.

\section{Test for terpenes}

Salkowski's test: Extracts were treated with chloroform and filtered. The filtrates were treated with few drops of Conc. Sulphuric acid, shaken and allowed to stand. No golden yellow color indicates the absence of tri terpenes.

Copper acetate test: Extracts were dissolved in water and treated with 3-4 drops of copper acetate solution. Formation of emerald green color indicates the presence of di terpenes.

\section{Test for phenols}

Ferric chloride test: $5 \mathrm{ml}$ solution of the extract was taken in a test tube. Then $1 \mathrm{ml}$ of 5\% Ferric chloride solution was added. Greenish black precipitate is formed and indicates the presence of Phenols.

\section{Test for proteins}

Xanthoproteic test: The extracts were treated with 4-5 drops of conc. Nitric acid. Formation of yellow color indicates the presence of proteins.

Cytotoxicity screening: Brine shrimp lethality bioassay is widely used in the bioassay for the bioactive compounds by the method of Meyer (Meyer et al., 1982). Measured amount of each of test samples were taken and dissolved in measured amount of pure dimethyl sulfoxide (DMSO) to get stock solutions. Then the solution was serial diluted to $400,200,100$, $50,25,12.5,6.25,3.125,1.563,0.781 \mu \mathrm{g} / \mathrm{mL}$ with sea water. Then $2.5 \mathrm{ml}$ of plant extract solution was added to $2.5 \mathrm{ml}$ of sea water containing 10 nauplii. In the present study vincristine sulphate was used as positive control. Measured amount of DMSO was added to each of three pre-marked test tubes containing $4.9 \mathrm{ml}$ of simulated sea water and 10 shrimp nauplii to use as negative control groups.

Anthelmintic activity: The anthelmintic assays are carried out as per the Vidyadhar method with minor modifications (Vidyadhar et al., 2010). Adult earthworms are used to study the anthelmintic activity. The earth worms (Phertima posthuma) are of $3-5 \mathrm{~cm}$ in length and $0.1-0.2 \mathrm{~cm}$ in width, weighing $0.8-3.04 \mathrm{~g}$ are used for all experiment protocols. The earthworms resembled the intestinal earth worm parasites of human 
beings both anatomically and physiologically and hence are used to study the anthelmintic activity. Albendazole is used as reference standard.

Collection of earthworms: Earthworms ( $P$. posthuma) were collected from moist soil in the campus of Noakhali Science and Technology University. Collected earthworms are thus washed with normal saline to remove all the fecal matter and waste surrounding their body.

Administration of extract: Aqueous extract of $A$. campanulatus, A. marina and $L$. sarmentosa at different concentrations were prepared by diluting the stock solution, using normal saline and its final volume was made up to $10 \mathrm{ml}$. Six groups of earthworms two in each group with equal size were released into $10 \mathrm{ml}$ of desired concentration of extracts and drug.

Administration of albendazole: Albendazole was prepared by dissolving them in normal saline at a concentration of $15 \mathrm{mg} / \mathrm{ml}$ (Vidyadhar et al., 2010).

Application of earthworms in the test sample solutions: Earthworms were divided into six Petri-dish each containing two earthworms. Five groups were used to the five concentrations of methanol extracts of experimental plants. One group was used as reference standard and another control group. Continuous observation was made to notice any physical change in the earthworms. The time of paralysis was recorded when no movement of any sort could be observed except the worms were shaken vigorously. Time for death of worms were recorded after ascertaining that the Worms neither moved when shaken vigorously nor when dipped in warm water at $50{ }^{\circ} \mathrm{C}$.

\section{Results}

Phytochemical Screening: Phytochemical screening revealed the presence of phenols, flavonoids, tannin, saponin, alkaloids, glycosides, phytosterols and carbohydrate in the experimental plant extracts which is showed in table 1.
In the phytochemical screening it was found that the methanol extract of A.campanulatus is rich in carbohydrates, alkaloids, reducing sugar, protein, phenols, phytosterols and saponin, A. marina is rich in flavonoids, carbohydrate, alkaloids, glycosides, phenols, protein, reducing sugar, cardiac glycoside and L. sarmentosa contains diterpines andalkaloids, carbohydrates, saponins, glycosides, phytosterols, and tannins.

Cytotoxic activity: In this study all crude extracts showed positive result indicating that test samples were biologically active. Each of the test samples showed different mortality rates at different concentrations. By using the process developed by Meyer, $\mathrm{LC}_{50}$ of crude methanol extracts were determined and the results are presented in table 2 .

The $\mathrm{LC}_{50}$ values of crude methanolic extract of $A$. campanulatus were found to be $12.45,14.95,13.02$, $15.83 \mu \mathrm{g} / \mathrm{ml}$ respectively. The positive control vincristine sulphate showed $\mathrm{LC}_{50}$ value of 0.839 . The $\mathrm{LC}_{50}$ value of methanol extract of A. marina was found to be $1.345 \mu \mathrm{g} / \mathrm{ml}$. From the results of the brine shrimp lethality bioassay it can be well predicted that the methanol extract possesses cytotoxic properties.

Anthelmintic activity: Time recorded for paralysis and death of earthworms for crude methanol extracts of A.campanulatus, A. marina and L. sarmentosa and standard drug are given below in table 3 .

All values represent Mean $\pm S E M ; n=6$ in each group. The extracts of the Amorphophallus campanulatus, Avicennia marina and Launaea sarmentosa displayed anthelmintic activity in dose dependent manner as shown in table 3. The predominant effect of Albendazole (Standard) on the worm is to cause a flaccid paralysis that result in expulsion of the worm by peristalsis. The extracts demonstrated paralysis as well as death of worms simultaneously which is comparable to albendazole especially at higher concentration. 
Table 1. Results of different group tests of methanol extracts of A. campanulatus, A. marina, L. sarmentosa.

\begin{tabular}{|c|c|c|c|}
\hline Sl. No. & Phytochemicals & Plants & Results \\
\hline \multirow[t]{3}{*}{1} & Alkaloids & a) A. campanulatus & + \\
\hline & & b) A. marina & + \\
\hline & & c) L. sarmentosa & + \\
\hline \multirow[t]{3}{*}{2} & Carbohydrates & d) A. campanulatus & + \\
\hline & & e) A. marina & + \\
\hline & & f) L. sarmentosa & + \\
\hline \multirow[t]{3}{*}{3} & Saponins & g) A. campanulatus & + \\
\hline & & h) A. marina & - \\
\hline & & i) L. sarmentosa & + \\
\hline \multirow[t]{3}{*}{4} & Phytosterols & j) A. campanulatus & + \\
\hline & & k) A. marina & - \\
\hline & & 1) L. sarmentosa & + \\
\hline \multirow[t]{3}{*}{5} & Phenols & m) A. campanulatus & + \\
\hline & & n) A. marina & + \\
\hline & & o) L. sarmentosa & - \\
\hline \multirow[t]{3}{*}{6} & Cardiac & p) A. campanulatus & + \\
\hline & & q) A. marina & + \\
\hline & & r) L. sarmentosa & - \\
\hline \multirow[t]{3}{*}{7} & Flavonoids & s) A. campanulatus & - \\
\hline & & t) A. marina & + \\
\hline & & u) L. sarmentosa & - \\
\hline \multirow[t]{3}{*}{8} & Proteins and amino acids & v) A. campanulatus & + \\
\hline & & w) A. marina & + \\
\hline & & x) L. sarmentosa & - \\
\hline \multirow[t]{3}{*}{9} & Terpenes & y) A. campanulatus & - \\
\hline & & z) A. marina & - \\
\hline & & aa) L. sarmentosa & - \\
\hline \multirow[t]{3}{*}{10} & Gum & bb) A. campanulatus & - \\
\hline & & cc) A. marina & - \\
\hline & & dd) L. sarmentosa & - \\
\hline
\end{tabular}

Table 2. Results of the test sample of A. campanulatus, A. marina and $L$. Sarmentosa.

\begin{tabular}{lccc}
\hline Sample & $\mathrm{LC}_{50}(\mu \mathrm{g} / \mathrm{ml})$ & Regression equation & $\mathrm{R}^{2}$ \\
\hline Vincristine sulphate (Positive control) & 0.839 & $\mathrm{y}=34.02 \mathrm{x}+52.58$ & 0.952 \\
Crude methanol extract(tuber) & 0.0005 & $\mathrm{Y}=34.46+6.776$ & 0.921 \\
[A.campanulatus] & & & \\
Crude methanol extract (Leaves) [A. marina] & 1.345 & $\mathrm{Y}=22.348 \mathrm{x}+47.123$ & 0.969 \\
Crude methanol extract [L. sarmentosa] & 15.652 & $\mathrm{y}=37.85 \mathrm{x}+4.785$ & 0.977 \\
\hline
\end{tabular}




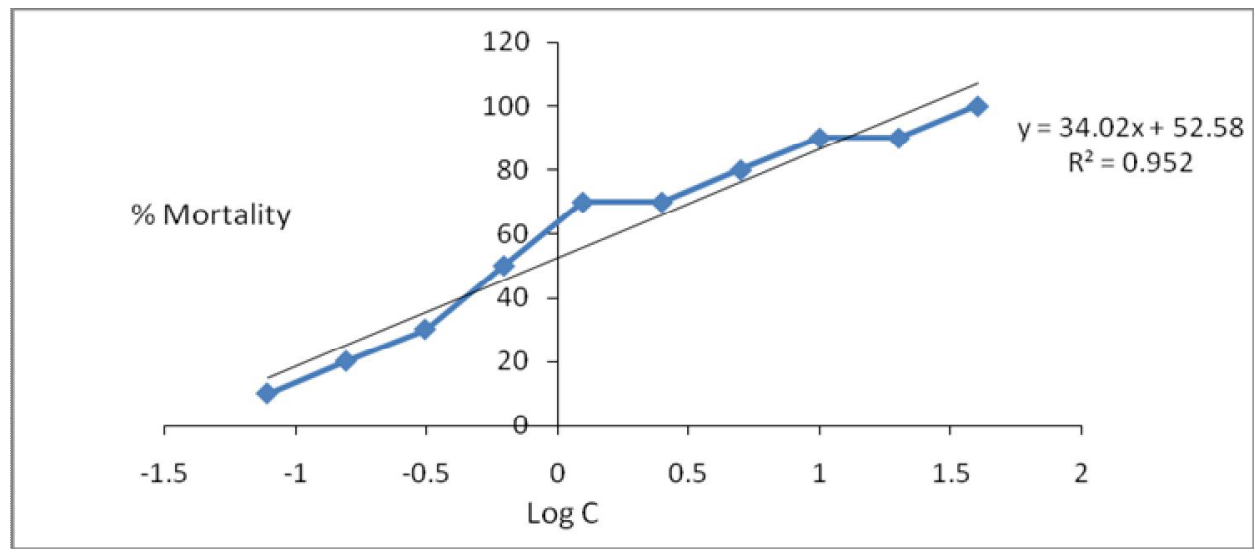

Figure 1. Effect of vincristine sulphate on brine shrimp nauplii.

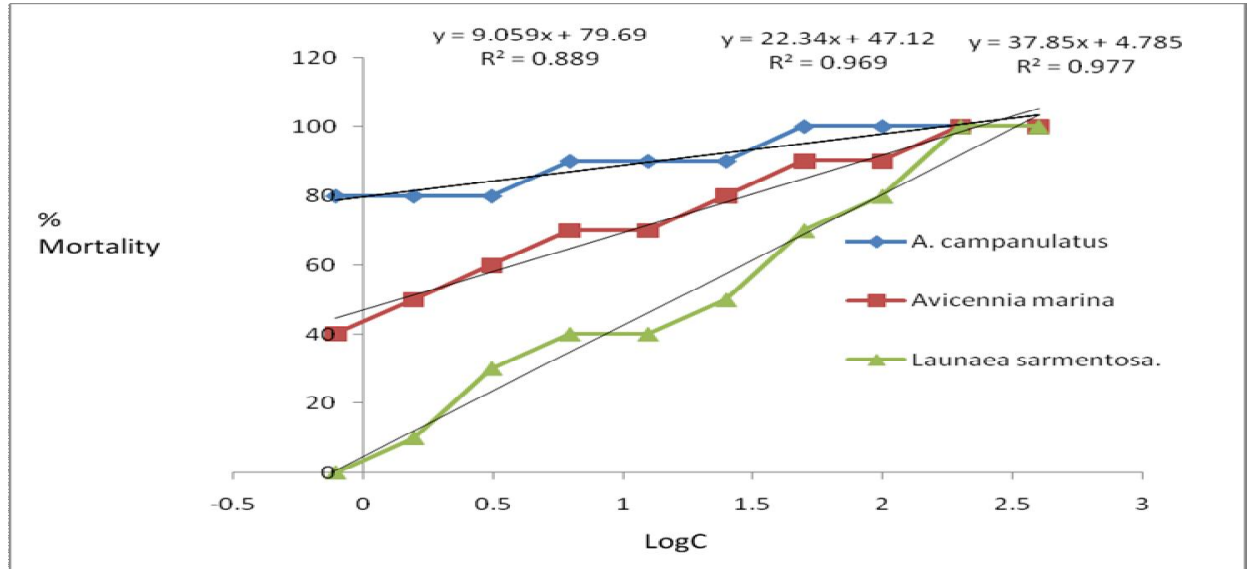

Figure 2. Effect of crude methanol extracts on brine shrimp nauplii.

Table 3. Results of the anthelmintic activity of A. campanulatus, A. marina and L. sarmentosa.

\begin{tabular}{|c|c|c|c|}
\hline Test substance & Concentration $(\mathrm{mg} / \mathrm{ml})$ & Paralysis time & Death time (min) \\
\hline standard & 10 & $35.33 \pm 0.58$ & $71.33 \pm 1.15$ \\
\hline \multirow[t]{4}{*}{ A. campanulatus } & 10 & $34.66 \pm 0.65$ & $53 \pm 0.82$ \\
\hline & 20 & $32.66 \pm 0.34$ & $46.33 \pm 0.41$ \\
\hline & 30 & $26.66 \pm 0.72$ & $42 \pm 0.81$ \\
\hline & 40 & $24.66 \pm 0.37$ & $38.33 \pm 0.27$ \\
\hline \multirow[t]{4}{*}{ A. marina } & 10 & $41.00 \pm 2.22$ & $63.00 \pm 1.59$ \\
\hline & 20 & $30.66 \pm 2.36$ & $52.00 \pm 2.33$ \\
\hline & 30 & $25.16 \pm 1.88$ & $49.16 \pm 2.45$ \\
\hline & 40 & $19.00 \pm 1.46$ & $32.66 \pm 0.95$ \\
\hline \multirow[t]{4}{*}{ L.sarmentosa } & 10 & $84.00 \pm 0.84$ & $77.4 \pm 0.24$ \\
\hline & 20 & $62.6 \pm 0.40$ & $125.8 \pm 1.16$ \\
\hline & 30 & $46.8 \pm 0.86$ & $104.6 \pm 0.40$ \\
\hline & 40 & $37.2 \pm 0.97$ & $88.2 \pm 1.61$ \\
\hline
\end{tabular}




\section{Conclusion}

It can be concluded that, the extracts of the Amorphophallus campanulatus, Avicennia marina and Launaea sarmentosa revealed significant cytotoxic and anthelmintic activity. Extracts contain different alkaloids, carbohydrates, saponins, phytosterols, phenols, flavonoids and amino acids that have huge phytochemical values. Though, further studies are needed to isolate and reveal the active compounds contained in the extracts responsible for pharmacological activities.

\section{Competing interests}

The authors declare that they have no competing interests.

\section{Authors' contributions}

MMR made significant contribution to conception and design of the study. GSR and MNA participated in data collection and analysis. SMS contributed in acquisition of data and drafting of the manuscript. $\mathrm{AB}$ and FAC have made substantial contribution to the interpretation of data and its presentation. AI contributed in data analysis and statistical studies. KS revised the manuscript for intellectual content. All authors read and approved the final manuscript.

\section{References}

Bandaranayake, W.M. 2002. Bioactive compounds and chemical constituents of mangrove plants. Wetland Ecol. Manage 10, 421-452.

Bobbarala, V., Vadlapudi, V.R. and Naidu, K.C.2009. Antimicrobial potentialities of mangrove plant Avicennia marina. J. Prote. Res. 2, 1019-1021.

Boland, D.J. 1984. Forest Trees of Australia (Fourth edition revised and enlarged). CSIRO Publishing, Collingwood, Victoria, Australia. ISBN 0-643-05423-5.

Bundy, D.A. 1994. Evaluation of anthelmintic activity of Bambusa Arundinacea, Trans Royal Soc. Trop Med. Hyg. 8, 259-261.

Duke, N.C., Benzie, J.A.H. and Goodall, J.A. 1998. Genetic structure and evolution of species in the mangrove genus Avicennia (Avicenniaceae) in the Indo-West Pacific. Evolution 52, 1612-1626.

Kirtikar, K. and Basu, B.D. 1935. Indian Medicinal Plants, Vol. II. p. 756
Ghani, A. 2003. Medicinal Plants of Bangladesh, 2nd edition, pp. 1-2, 55-57, 402-500.

Harborne, J.B. 1998. Phytochemical methods: A guide to modern techniques of plant analysis, Springer international, 3rd edition.

Kala, S., Johnson, M., Janakiraman, N., Arockiaraj, A.A., Raj, S.A. and Bosco, D. 2011. Pharmacognostic and Phytochemicalstudies on some selectedethnomedicinal plants of Tamilnadu, South India, Int. J. Med. Arom. Plants 2, 89-94.

Kathiresan, K. and Bingham, B.L. 200. Biology of mangroves and mangrove ecosystems. Adv. Mar. Biol. 40, 81-251.

Khafagi, I., Gab-Alla, A., Salama, W. and Fouda, M. 2003. Biological activities and phytochemical constituents of the gray mangrove Avicennia marina (Forssk.) Vierh. Egyptian J. Botany 5, 62-69.

Kiritikar, K.R. and Basu, B.D. Indian medicinal plants, vol: 141991, 1

Launaeasarmentosa (Willd.) Sch. Bip. exKuntze, Royal botanic gardens (KEW), (1992) volume: 6 part: 1

Meyer, B.N., Ferrigni, N.R., Putnam, J.E. and Jacobsen, L.B. 1982. Brine shrimp: A convenient general bioassay for active plant constituents. Planta Medica 45, 31-34.

Mian, R.H. and Roxrigues-Kabana, R. 1982. Organic amendment with high tannin and phenolic compound for the control of Meloidogynearenaria in infested soil. Nematotropica 12, 71-74.

Miles, D.H., Kokpol, U., Chittawong, V., Tip-Pyang, S., Tunsuwan, K. and Nguyen, C. 1999. Mangrove forestsThe importance of conservation as a bioresource for ecosystem diversity and utilization as a source of chemical constituents with potential medicinal and agricultural value. IUPAC 70, 1-9.

Nadkarni, K.M. 1982. Indian Materia Medica, Popular Prakashan, Mumbai 1, 729.

Nagalapur, S.K. and Paramjyothi. S. 2010. In vitro antioxidant activity of Launaeapinnatifidac ass leaves. The Bioscan 5, 105-108.

Neem: A tree for solving global problems. National Academy Press, 1992.

Pullaiah, T. 2006. Encyclopedia of world medicinal plants. Regency 1, 1217.

Pushpangadan, P. and Kumar, B. 2005. WTO and the Biodiversity Act of India. Ethnobotany 17, 2-12.

Ravikumar, S., Gnanadesigan, M., Suganthi, P. and Ramalakshmi, A. 2010. Antibacterial potential of chosen mangrove plants against isolated urinary tract infectious bacterial pathogens. Int. J. Med. Med. Sci. 2, 94-99. 
Rich, J.R., Rali, G.S. and Oppenmann, C.H. 1989. Influence of castor bean (Ricinuscommunis) lectin (Ricinin) on mortality of Meloidogyne incognita. Nematotropica 19, 99-103.

Salih, Y., Harisha, C.R., Vinay, J. and Acharya, R. 2013. Pharmacognostical evaluation of Launaeasarmentosa (Willd.) schultz-bip. Ex Kuntze root. J. Res. in Ayurveda 34, 90-94.

Sondhi, S.M., Shahu, R. and Magan, A. 1994. Indian Drugs 31, 317-320..
Spalding, M., Kainuma, M. and Collins, L. 2010. World atlas of mangroves.

Vidyadhar, S., Saidulu, M., Gopal, T.K., Chamundeeswari, D., Rao, U. and Banji, D. 2010, Int. J. Pharma and Bio Sci. 2010; 1, 1-4. 20

Zandi, K., Taherzadeh, M., Yaghoubi, R., Tajbakhsh, S., Rastian, Z., Fouladvand, M. and Sartavi, K. 2003. Antiviral activity of Avicennia marina against herpes simplex virus type 1 and vaccine strain of poliovirus (an in vitro study). J. Med. Plant Res. 3, 771-775. 